DOI: https://doi.org/10.31933/dijdbm.v2i3 Received: 21 January 2021, Revised: 18 March 2021, Publish: 18 March 2021

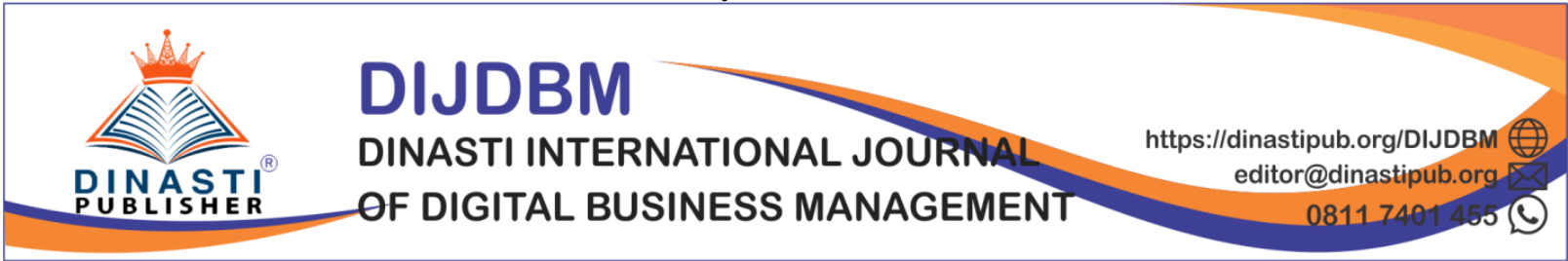

\title{
ANALYSIS THE EFFECT OF MACROECONOMIC FACTORS ON INDONESIA 10-YEAR GOVERNMENT BOND YIELD
}

\author{
Chyntia Juliana Pratiwi ${ }^{1}$, Matrodji H. Mustafa ${ }^{2}$ \\ ${ }^{1)}$ Master of Management, Mercu Buana University Jakarta, Indonesia, chynt90@ gmail.com \\ ${ }^{2)}$ Master of Management, Mercu Buana University Jakarta, Indonesia, \\ matrodji.mustafa@mercubuana.ac.id
}

\begin{abstract}
The purpose of this research is to analyze macroeconomics, namely Inflation, Gross Domestic Product, Exchange Rates, Interest Rates and Sovereign Risk to Indonesia 10Year Government Bond Yield. The population in this study were all government bond yield tenors of the benchmark series for the period 2017 to 2019. The type of research used in this study is causal associative research. The research sample is Indonesian government bonds with a tenor of 10 years. The sample amounted to 36 data. The data analysis technique used multiple regression analysis method. The results showed that inflation and Gross Domestic Product have no effect on the Indonesia 10-Year Government Bond Yield. Exchange Rates, Interest Rates and Sovereign Risk have a positive and significant effect on the Indonesia 10Year Government Bond Yield.
\end{abstract}

Keyword: Inflation, Gross Domestic Product, Exchange Rates, Interest Rates, Sovereign Risk, Indonesia 10-Year Government Bond Yield.

\section{INTRODUCTION}

Every year, the issuance of Government bonds is increasing. The highest increase in outstanding was achieved in 2016 of $24.35 \%$ compared to 2015 . The consecutive increases indicate the increasing demand for Government bonds in the capital market.

Tabel-1. IDR Government Bond Activities

\begin{tabular}{|c|c|r|r|}
\hline Year & Series & $\begin{array}{c}\text { Outstanding } \\
\text { (Rp Trillion) }\end{array}$ & $\begin{array}{c}\text { Change of } \\
\text { Outstanding (\%) }\end{array}$ \\
\hline 2011 & 89 & 723,61 & 12,85 \\
\hline 2012 & 92 & 820,27 & 13,36 \\
\hline 2013 & 96 & 995,25 & 21,33 \\
\hline 2014 & 90 & $1.209,96$ & 1,57 \\
\hline 2015 & 91 & $1.425,99$ & 24,35 \\
\hline 2016 & 92 & $1.773,28$ & 19,27 \\
\hline 2017 & 91 & $2.115,07$ & 11,83 \\
\hline 2018 & 97 & $2.365,35$ & 16,38 \\
\hline 2019 & 97 & $2.752,74$ & \\
\hline
\end{tabular}

Source: IDX, data processed (2020)

The Directorate General of Budget Financing and Risk Management (DJPPR) (2020) stated that Total ownership of Government Securities traded as of December 31, 2019 was Rp 2,752.74 trillion. Foreign ownership of Government Securities was still dominated at 
$38.57 \%$, banks at $21.12 \%$ and Bank Indonesia at $9.54 \%$. This data shows that Government Securities are an attractive instrument for investors in the capital market.

Tabel-2. Ownership of IDR Tradable Government Securities (SBN) (Rp Triliun)

\begin{tabular}{|c|c|c|c|c|c|c|c|c|c|}
\hline \multirow{2}{*}{ institutions } & 31-Des-15 & 31-Dec-16 & 31-Dec-17 & 31-Dec-18 & 31-Mar-19 & 30-Jun-19 & 30-Sep-19 & 31-Dec-19 & \multirow{2}{*}{$\begin{array}{c}\text { Porsi } \\
\text { PerDes'19 }\end{array}$} \\
\hline & TOTAL & TOTAL & TOTAL & TOTAL & TOTAL & TOTAL & TOTAL & TOTAL & \\
\hline BANK & 350.07 & 399.46 & 491.61 & 481.33 & 649.10 & 588.77 & 637.12 & 581.37 & $21.12 \%$ \\
\hline Bank Indonesia - Net & 148.91 & 134.25 & 141.83 & 253.47 & 132.03 & 153.88 & 167.99 & 262.49 & $9.54 \%$ \\
\hline NON-BANK & 962.86 & $1,239.57$ & $1,466.33$ & $1,633.65$ & $1,746,86$ & $1,788.39$ & $1,859.22$ & $1,908.88$ & $69.34 \%$ \\
\hline Mutual Funds & 61.60 & 85.66 & 104.00 & 118.63 & 113.05 & 106.76 & 125.49 & 130.86 & $4.75 \%$ \\
\hline Insurance & 171.62 & 238.24 & 150.80 & 201.59 & 208.35 & 212.78 & 215.55 & 215.01 & $1.01 \%$ \\
\hline Foreign & 558.52 & 665.81 & 836.15 & 893.25 & 967.12 & 988.75 & $1,029.39$ & $1,061.86$ & $38.57 \%$ \\
\hline Pension Fund & 49.83 & 87.28 & 198.06 & 212.88 & 226.13 & 237.04 & 250.44 & 256.66 & J.JL/0 \\
\hline Individual & 42.53 & 57.75 & 59.84 & 73.07 & 82.57 & 77.23 & 77.66 & 81.18 & $2.95 \%$ \\
\hline Other & 78.76 & 104.84 & 117.48 & 134.22 & 149.64 & 165.82 & 160.70 & 163.32 & $\%$ \\
\hline TOTAL & $1,461.85$ & $1,773.28$ & $2,099.77$ & $2,368.45$ & $2,527.99$ & $2,531.04$ & $2,664.33$ & $2,752,74$ & $100.00 \%$ \\
\hline
\end{tabular}

Source: Directorate General of Budget Financing and Risk Management (DJPPR), data processed (2020)

The data above indicates that the bond yield of the Republic Indonesia is still considered attractive and competitive in the domestic and global markets. Bond issuers expect low yield because they will minimize the cost of funds such as the coupon rate given, meanwhile, investors expect high yields to maximize returns on their placement of funds, especially for investors who place their funds in bonds until maturity.

Every year the Director General of Budget Financing and Risk Management implements the provisions of the Minister of Finance Regulation Number 234 / PMK.08 / 2016, stipulating the Director General of Budget Financing and Risk Management Decree on Benchmark Series Government Bonds. The benchmark series consists of 4 tenors, namely 5 , 10,15 and 20 years.

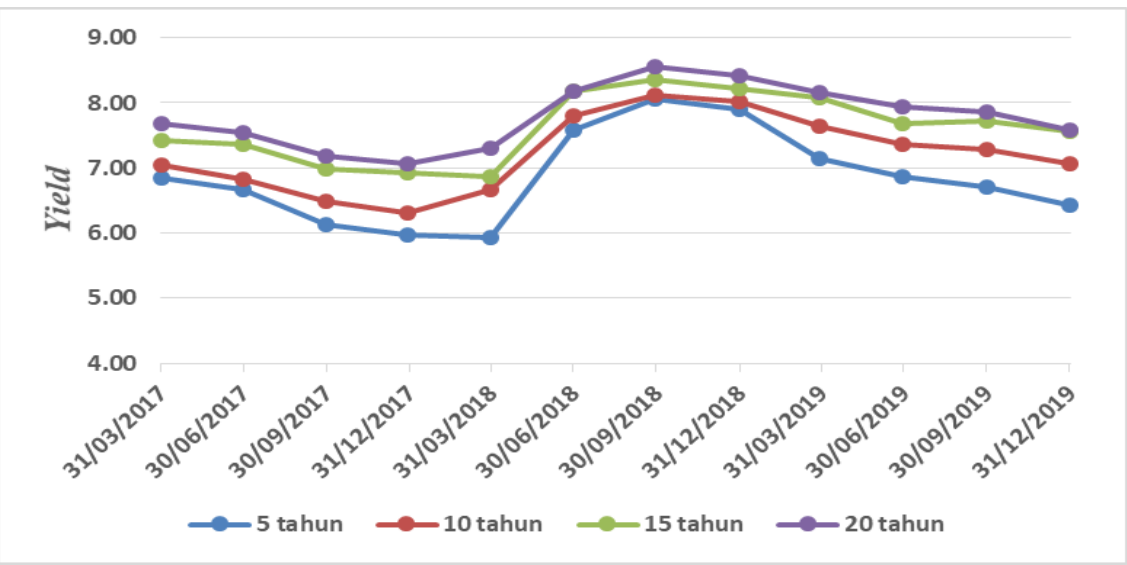

Source: Bloomberg, data processed (2020)

Figure-1. The Movement of Government Bond Benchmark Series Yields Indonesia for the period $2017-2019$

The data in Figure 1 shows the movement in the yield of the Indonesian Government bond benchmark series where there was a significant increase in the September 2018 period. This was more due to global uncertainty such as the trade war between the United States and 
China that was getting higher, the increase in the Fed Fund Rate by 75 bps from $1.50 \%$ to $2.25 \%$, an increase in oil prices and internal factors, namely an increase in BI (7 Days BI Reverse Repo) rate of 150 bps from early 2018 to September 2018 of $4.25 \%$ to $5.75 \%$. This affects investors' perceptions, which will impact yield fluctuations in Government Securities.

Table-3. The 10-year Yield of the BBB Sovereign Credit Rating as of December 31, 2019

\begin{tabular}{|c|c|}
\hline \multicolumn{1}{|l|}{ Country } & Yield 31 Dec 2019 \\
\hline Bulgaria & $0.26 \%$ \\
\hline Indonesia & $7.06 \%$ \\
\hline Hungary & $2.01 \%$ \\
\hline Italy & $1.41 \%$ \\
\hline Mexico & $6.91 \%$ \\
\hline Portugal & $0.44 \%$ \\
\hline
\end{tabular}

Source: Bloomberg, data processed (2020)

Based on table 3, when compared with countries that have the same ranking as Indonesia, namely BBB (Investment Grade), Indonesia is one of the countries that has a high yield level. The yield movement of a bond is highly dependent on market movements originating from the market participants themselves. In general, the higher level of investment in a country, indicate the lower yield movement will be because it shows a good market perception of that country with the increasing ability of a country to pay its obligations and vice versa. This market perception cannot be separated from the macroeconomic conditions of a country which can be assessed from the economic conditions, the rate of return provided and the risk of a country.

Table-4. Benchmark series Fair Yield and Fair Price SUN 2019

\begin{tabular}{|l|l|c|c|c|c|c|c|c|c|}
\hline $\begin{array}{c}\text { SUN Seri } \\
\text { Benchmark } \\
\begin{array}{c}\text { Year } \\
2019\end{array}\end{array}$ & Maturity & \multicolumn{2}{|c|}{$\begin{array}{c}\text { 29 March } \\
2019\end{array}$} & \multicolumn{2}{|c|}{ 28 June 2019 } & \multicolumn{2}{|c|}{30 Sept 2019 } & \multicolumn{2}{c|}{31 Dec 2019} \\
\cline { 3 - 10 } & & $\begin{array}{c}\text { Fair } \\
\text { Yield }\end{array}$ & $\begin{array}{c}\text { Fair } \\
\text { Price }\end{array}$ & $\begin{array}{c}\text { Fair } \\
\text { yield }\end{array}$ & $\begin{array}{c}\text { Fair } \\
\text { Price }\end{array}$ & $\begin{array}{c}\text { Fair } \\
\text { yield }\end{array}$ & $\begin{array}{c}\text { Fair } \\
\text { Price }\end{array}$ & $\begin{array}{c}\text { Fair } \\
\text { Yield }\end{array}$ & $\begin{array}{c}\text { Fair } \\
\text { Price }\end{array}$ \\
\hline FR0077 & 5 Years & 7.08 & 104.43 & 6.81 & 105.36 & 6.68 & 105.65 & 6.36 & 106.63 \\
\hline FR0078 & 10 Years & 7.59 & 104.61 & 7.33 & 106.34 & 7.27 & 106.72 & 7.07 & 107.96 \\
\hline FR0068 & 15 Years & 8.05 & 102.83 & 7.64 & 106.41 & 7.70 & 105.80 & 105.80 & 107.20 \\
\hline FR0079 & 20 Years & 8.12 & 102.52 & 7.90 & 104.66 & 7.83 & 105.45 & 105.45 & 106.88 \\
\hline
\end{tabular}

Source: Indonesia Bond Pricing Agency (PHEI), data processed (2020)

Table 4 shows that the movement of yield and price in the secondary market is inversely proportional to where the yield decreases, the price will increase, however, yield is more of a reference for the profits that investors get than prices because it reflects coupons, tenors and risks. In addition, Table 4 shows that the longer the tenor of a bond, the higher the yield given. 
This study aims to find empirical evidence of the effect of macroeconomic factors on the Indonesia 10-Year Government Bond Yield for the period 2017 - 2019.

\section{LITERATURE REVIEW}

Term Structure Interest Rate. According to Martellini at al. (2003), the term structure Interest Rate is a series of interest rate sorted based on a certain maturity date. There are four theories that explain the yield curve, namely: The Pure Expectations Theory, The Pure Risk Premium Theory, The Market Segmentation Theory and The Biased Expectations Theory.

Bond. Bonds can be interpreted as one of the securities instruments in the form of debt issued by a company and providing returns to investors in the form of coupons that are paid periodically and repayment of principal debt at maturity. The bond yield is a measure the return of a bond to investors (Fabozzi, 2002). Government bonds are issued by the government to support the country's development. Government bonds traded on the capital market are in the form of Government Securities. Tandelilin (2010) states that investors must know that government bonds must reflect investment and risk burdens, can be used as a guide for other bond movements in the capital market, used as an instrument to support country development, facilitate bond pricing and evaluation and become a risk management tools.

Inflation. Sihombing (2014) explains the Consumer Price Index as an approach to public consumption expenditure. An increase in the Consumer Price Index will reduce public consumption expenditure, which will result in an economic slowdown. The condition of the economic slowdown will increase the risk premium so that the yield will increase. Sihombing (2014) concluded that the CPI is a measure of inflation.

Gross Domestic Product. Mankiw, et al (2012) argue that Gross Domestic Product is the final market value of all goods and services produced by a country in a certain period. The increase in Gross Domestic Product shows that a country's economy is in a positive position to invest due to decreasing country risk.

Exchange Rates. Madura (2009) argues that investors will make an investment in a country with a strong Exchange Rates. This will affect the increase in cash inflow in a country, the value of the currency will be increasingly appreciated and show a decrease in the risk level of the resulting exchange rate difference. In addition, the appreciation and depreciation of a currency against foreign currencies indicates the fundamental condition and market sentiment towards that country.

Interest Rates. In investing decisions, the factor of Interest Rates is taken into consideration by investors. Murtianingsih (2012) explains that increased Interest Rates indicate a large cost of capital so that an increase in Interest Rates also indicates an increased return on investment. Interest rates are a reference for buyers of debt securities such as bonds as a basic comparison of the rate of expected return.

Sovereign Risk. Sovereign Risk is the risk that occurs in a country where there is an opportunity to fail the payment of interest and principal of debt. Sovereign risk is an important factor seen by an investor in investing their funds in a country. The level of a country's risk can be seen from the Credit Default Swap (CDS). The higher Credit Default Swap, the higher risk for the country and vice versa. The level of Credit Default Swap is influenced by fundamentals which are reflected in the condition of its economy and global conditions that affect the country. Based on the literature above, a research framework is prepared that shows the relationship between variables 


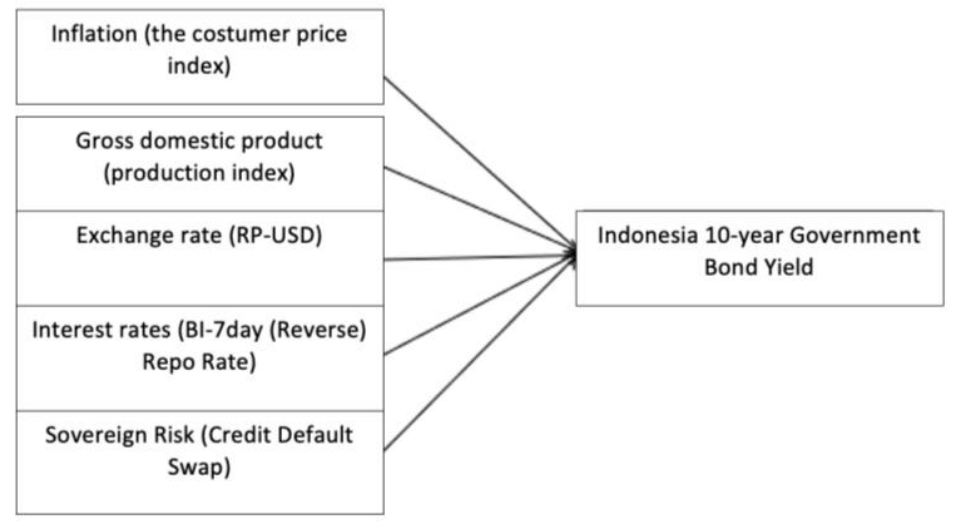

Figure-2. Research Framework

\section{RESEARCH METHODOLOGY}

The type of research used in this research is causal associative research which is useful for analyzing the relationship between the variables in this research, the independent variable against the dependent variable by testing the hypothesis with statistical tests. The operational definition for measuring each variable is described in Table-5

Table-5. Operational Definition and Variable Measurement

\begin{tabular}{|c|l|l|c|}
\hline No & \multicolumn{1}{|c|}{ Variable } & \multicolumn{1}{|c|}{ Measurement } & Scale \\
\hline 1. & $\begin{array}{l}\text { Indonesia } 10 \text {-Year } \\
\text { Government Bond Yield }(\mathrm{Y})\end{array}$ & YTM & Percent \\
\hline 2 & Inflation $\left(\mathrm{X}_{1}\right)$ & consumer price index & Nominal \\
\hline 3 & Gross domestic product $\left(\mathrm{X}_{2}\right)$ & Production Index & Rominal \\
\hline 4 & Exchange rate $\left(\mathrm{X}_{3}\right)$ & $\begin{array}{l}\text { Rupiah exchange rate against US } \\
\text { Dollar }\end{array}$ & Pupiah \\
\hline 5 & Interest Rate $\left(\mathrm{X}_{4}\right)$ & BI-7 day (Reverse) Repo Rate \\
\hline 6 & Sovereign Risk $\left(\mathrm{X}_{5}\right)$ & Credit Default Swap & Nominal \\
\hline
\end{tabular}

The research population comprised all of the benchmark bond yield tenor data issued by the government, totaling were 144 data. The sample in this study is monthly data for the period 2017 - 2019 so that 36 observational data are obtained. The data analysis technique used to analyze the effect of independent variables on the dependent variable is multiple linear regression models. The regression equation proposed is:

$$
G I D N 10 Y R_{t}=a+b_{1} I H K+b_{2} I P+b_{3} K U R S+b_{4} B I 7 D R R+b_{5} C D S+\mathrm{e}
$$

Information:

GIDN10YR : Indonesia 10-Year Government Bond Yield

a : Constant

$\mathrm{b} \quad: b_{1}, b_{2}, b_{3}, b_{4}, b_{5}$ is the regression coefficient

IHK : Consumer Price Index

IP : Production Index

KURS : Rupiah exchange rate against US Dollar

BI7DRR : BI-7 day (Reverse) Repo Rate

CDS : Credit default Swap

e : Error 


\section{RESEARCH RESULTS AND DISCUSSION}

Descriptive statistics on the research variables are presented in Table-6.

Table-6. Descriptive Statistics of Research Variables

\begin{tabular}{|l|r|r|r|r|r|}
\hline & \multicolumn{1}{|c|}{ N } & \multicolumn{1}{c|}{ Min } & \multicolumn{1}{c|}{ Max } & \multicolumn{1}{c|}{ Mean } & \multicolumn{1}{c|}{$\begin{array}{c}\text { Std. } \\
\text { Deviation }\end{array}$} \\
\hline Inflation & 36 & 127.94 & 139.07 & 133.5244 & 3.56056 \\
\hline Gross domestic product & 36 & 125.18 & 158.00 & 142.9758 & 7.31311 \\
\hline Exchange rate & 36 & $13,319.00$ & $15,227.00$ & $13,932.0281$ & 499.82015 \\
\hline Interest Rate & 36 & 4.25 & 6.00 & 5.0972 & 0.66084 \\
\hline Sovereign Risk & 36 & 131.99 & 235.30 & 179.6583 & 25.84920 \\
\hline Indonesia 10-Year & 36 & 6.27 & 8.54 & 7.2908 & 0.58224 \\
Government Bond Yield & & & & & \\
\hline Valid N (listwise) & 36 & & & & \\
\hline
\end{tabular}

The lowest Consumer Price Index value occurred in January 2017, this was due to adequate demand at the beginning of the year with the availability of goods and the controlled exchange rate of the rupiah where there was an increase in international commodity prices. This triggered inflation to remain low and stable while the highest Consumer Price Index occurred in December 2019, this was due to increased consumption of the volatile food group, which recorded inflation in a seasonal pattern driven by increased demand towards the end of the year which coincided with school holidays. The highest inflation occurred in foodstuffs, followed by transportation.

The Gross Domestic Product has a small distribution and the data used are good data. The lowest Production Index occurred in June 2018 where economic growth was inseparable from manufacturing activity as reflected in the Purchasing Managers Index where the PMI June 2018 was recorded at the level of 50.3 which was lower than the previous month's level of 51.7. This is due to the weakening of people's purchasing power due to inflationary pressure, which refers to demand from consumers where output is slowing due to a slowdown in new orders by consumers. Meanwhile, the highest Production Index occurred in October 2019, this was more due to the easing of global financial uncertainty due to the US and China trade war, which increased investment flows to emerging market countries such as Indonesia. This has affected several manufactured export products, such as motor vehicles to ASEAN countries, and gold exports have grown positively.

The lowest Exchange Rate occurred in June 2017, this is more due to the monthly average, the rupiah recorded strengthening in June 2017. The strengthening of the rupiah is supported by positive domestic macroeconomic developments and reduced external risks. Positive sentiment on the domestic side of the increase in Indonesia's rating to investment grade also affected capital inflows and the strengthening of the rupiah throughout June 2017. From the external side, risks to the rupiah Exchange Rate tend to decline. The increasing Fed Funds Rate (FFR) at 25 bps in June 2017 has been fully anticipated by the market. Meanwhile, the highest exchange rate occurred in October 2018, this was due to the heating up of the Trade War between the United States (US) and China, as a result emerging market countries experienced exchange rate depreciation, including Indonesia. The pressure on the outflow of foreign funds occurred in line with the high level of global uncertainty, especially related to the tension in the Trade War between the US and several trading partner countries.

The lowest Interest Rate occurred in September 2017 to April 2018. Based on the results of the Board of Governors Meeting (RDG) of Bank Indonesia (BI) on September 2022 2017, BI decided to lower the benchmark Interest Rate by 25 bps from $4.50 \%$ to $4.25 \%$. It is hoped that the reduction in Interest Rates will support the improvement of banking 
intermediation in channeling credit and the sustainable recovery of the domestic economy. The decline in Interest Rates encourages the strengthening of the property sector, where the reduction in the benchmark Interest Rate will push down the property loan interest rate, which has the potential to improve the performance of listed companies. The highest Interest Rates occurred in November 2018 to June 2019, this was due to the high risk of uncertainty in global financial markets due to sluggish global economic growth, the dynamics of the increase in the Fed Fund Rate (FFR), and the high risk of trade tensions that triggered several central banks both developed and developing countries continue to raise their policy Interest Rates (tightening), including Indonesia.

The lowest Credit Default Swap occurred in December 2019, this was inseparable from domestic factors and global factors that occurred. Domestic factors include stable macroeconomic data and a stable rupiah exchange rate and global factors in the negotiations that took place between the US and China to reduce global uncertainty, which has brought foreign capital flows to emerging market countries such as Indonesia. Until the end of 2019, foreign ownership of Government Securities was 38.57\%. The highest Credit Default Swap occurred in October 2018, in line with the depreciation of the Rupiah that occurred in October 2018 where risk perceptions increased the uncertainty that occurred on global financial markets. The volatility of the rupiah was dominated by global factors, such as the effect of the increase in the Fed Fund Rate to the upward trend in the US Treasury and crude oil prices. This has prompted global investors to seek safer instruments.

The lowest yield occurred in January 2018, which was due to the stability of global and domestic economic conditions throughout 2017 which brought a positive signal in early 2018. Throughout 2017, the global economy was in a recovery phase in line with the improvement in prices of key commodities such as crude oil, mining and agriculture. The improvement in the global economy is not only experienced by the real sector, but also in the financial sector. Throughout 2017, the financial sector continued to experience rapid growth, both in Indonesia and globally. This is reflected in several positive indicators of financial market performance. Meanwhile, the highest yield occurred in October 2018, this was due to the strengthening of the US dollar and the increase in the yield of US treasury which was triggered by the tax reduction policy for companies which affected the yield of emerging market countries such as Indonesia.

\section{Multiple Linear Regression Model Testing Results}

Multiple Linear Regression Analysis is used to determine the effect of Inflation (IHK), Gross Domestic Product (IP), Rupiah Exchange Rate (KURS), Interest Rates (7DBIRR) and Sovereign Risk (CDS) as independent variables on Indonesia 10-Year Government Bond Yield (GIDN10YR) as the dependent variable.

Table-7. Results of Multiple Linear Regression Analysis Coefficients $^{\mathrm{a}}$

\begin{tabular}{|c|c|c|c|c|c|c|}
\hline \multicolumn{2}{|c|}{ Model } & \multicolumn{2}{|c|}{ Unstandardized Coefficients } & $\begin{array}{c}\text { Standardized } \\
\text { Coefficients } \\
\text { Beta }\end{array}$ & $\mathbf{t}$ & Sig. \\
\hline \multirow[t]{5}{*}{1} & (Constant) & 0.4365 & 2.515 & & 0.174 & 0.863 \\
\hline & Inflation & -0.0184 & 0.028 & -0.113 & -0.656 & 0.517 \\
\hline & Gross domestic product & 0.0015 & 0.006 & 0.018 & 0.241 & 0.811 \\
\hline & Exchange rate & 0.0004 & 0.000 & 0.323 & 2.526 & 0.017 \\
\hline & Interest Rate & 0.5105 & 0.099 & 0.579 & 5.174 & 0.000 \\
\hline
\end{tabular}




\begin{tabular}{|l|r|r|r|r|r|}
\hline Sovereign Risk & 0.0070 & 0.003 & 0.310 & 2.378 & 0.024 \\
\hline
\end{tabular}

Based on Table-7 the resulting regression equation is:

$$
\begin{gathered}
\text { GIDN10YR }=0,4365-0,0184 \mathrm{IHK}+0,0015 \mathrm{IP}+0,0004 \mathrm{KURS}+0,5105 \mathrm{BI} \mathrm{DRR}+ \\
0,0070 \mathrm{CDS}
\end{gathered}
$$

The results of this study indicate that there is no influence between inflation and Indonesia 10-Year Government Bond Yield. Inflation is one of the macro indicators of a country that shows changes in price increases in general and continuously over a certain period of time. Unstable inflation (high or too low) will create uncertainty for economic players. Unstable inflation will complicate investors' decisions to invest. As happened in June 2017, inflation level was recorded at $4.37 \%$ yoy where the 10 -year yield was $6.83 \%$, down from the previous month with lower inflation recorded in the previous month where the yield was higher. So it can be said that the effect of yield on inflation is still influenced by external, other internal factors and the risk appetite of investors in determining market timing in investing. The results of this study are not in line with research conducted by Sihombing \& Sundoro (2017). The Effect of Macroeconomic and Liquidity Factors on the Indonesian Government Bond yield curve. The results of the study found that there was a positive influence of inflation on bond yield curves, but in line with Listiawati \& Paramita's research (2018) The effect of interest rates, inflation, debt to equity ratio, and company size on bond yields in companies listed on the Indonesia Stock Exchange. The research found that inflation has no effect on bond yields.

Gross Domestic Product is an important internal indicator to determine the economic condition of a country in a certain period. The increase in Gross Domestic Product shows an increase in the economy for the country, however there are external factors that affect the movement of yield. For example, the heating up of the Trade War that occurred between the US and China had an impact on emerging market countries that had good economic conditions but their yields continued to move up. So it can be said that the increase in Gross Domestic Product is a positive signal to invest, while the yield movement is determined by other internal or external factors. The results of this study are not in line with the research conducted by Saputra dan Prasetiono (2014) Analysis of the factors that affect conventional bond yields in Indonesia. The research results found that GDP has a negative and significant effect on bond yields.

Exchange Rates will affect cash inflow or cash outflow in a country. In addition, the strengthening appreciation and depreciation of a currency against foreign currencies indicates the fundamental condition and market sentiment towards that country. Global uncertainty and global liquidity affect a country's exchange rate. So that when liquidity is high, even though the exchange rate condition is depression, investors will invest their funds while still paying attention to the risk appetite that investors have with the high demand for bonds, it will increase bond prices and the yield will gradually decrease. The results of this study are not in line with research conducted by Kurniasih \& Restika (2015) The Influence of Macroeconomic Indicators and Foreign Ownership on Government Bond Yields: A Case of Indonesia. The results of the study found that the rupiah exchange rate had a negative effect on government bond yields, but in line with $\mathrm{Yu}$ (2015) research on Determinant of Government Bond Yield in Spain, the exchange rate research had a positive effect on government bond yields. 
Interest rates are an important factor in making investment decisions. Interest rates are a reference for buyers of debt securities such as bonds as a basic comparison of the rate of expected return. When market interest rates change, it will affect the price of debt securities. When the market interest rate increases, it will affect the return on debt securities which will increase. The results of this study are in line with research conducted by Yuliawati \& Suarjaya (2017) The Effect of Bond Age, Interest Rates and Inflation on Government Bond Yields on the IDX. The results of the study found that the interest rate has a positive and significant effect on bond yields, but it is not in line with Wulandari's research (2017) The Effect of Interest Rate, Bond Rating and Debt to Equity Ratio (DER) on Corporate Bond Yield (Case Study of All Issuing Companies) Bonds Listed on the IDX for the 2013-2015 Period), which shows that the Interest Rate has a negative and insignificant effect on Bond Yield.

Sovereign Risk is the risk that occurs in a country where there is an opportunity to fail the payment of interest and principal of debt. Sovereign risk is an important factor seen by an investor in investing their funds in a country. The size of a country's risk can be seen from the Credit Default Swap (CDS). The higher the CDS, the higher the risk for the country and vice versa. The level of CDS is influenced by fundamentals which are reflected in the condition of its economy and global conditions that affect the country. The higher the risk of a country, the higher the returns a country must provide. The results of this study are in line with research conducted by Nielsen (2012) The Empirical Relationship between CDS Prices and Bond Yields after the Financial Crisis. The results of the study found that Credit Default Swaps affect the yield spread of the bond market and Shim \& Zhu (2010) The Impact of CDS Trading on the Bond Market: Evidence From Asia. The results of the study found that Credit Default Swap has a positive effect on the spread of the bond market, but this study is not in line with Naifar \& Abid's (2006) research, The Determinants of Credit Default Swap Rates: an Explanatory Study. The results showed that the Credit Default Swap has a negative effect on the yield curve.

\section{CONCLUSION}

The results showed that Exchange Rates, Interest Rates and Sovereign Risk had a positive and significant effect on the Indonesia 10-Year Government Bond Yield. Meanwhile, inflation and Gross Domestic Product have no effect on Indonesia 10-Year Government Bond Yield.

Investors are advised to make investments, especially in government bonds, which are expected to pay attention to the Exchange Rate, Interest Rate and Sovereign Risk of the issuing country because these macro factors have a significant effect on bond yields.

In making policy, the Government needs to considering the impact of the policies taken, especially on policies that can affect Exchange Rates, Interest Rates and Sovereign Risk which based on this research has a significant effect on government bond yields.

Further research can be done by increasing the tenor and research period and adding external factors such as US Treasury yield and The Fed Fund Rate.

\section{REFERENCES}

Abid, F., \& Naifar, N. (2006). The determinants of credit default swap rates: An explanatory study. International Journal of Theoretical and Applied Finance, 9(1), 23-42. https://doi.org/10.1142/S0219024906003445 
Badan Pusat Statistik. (2020). Inflasi. Diakses pada 2 Maret 2020, https://www.bps.go.id/ subject/3/inflasi.html

Bank Indonesia. (2020). Pengenalan Inflasi. Diakses pada 2 Maret 2020, https://www.bi.go.id/ id/moneter/inflasi/pengenalan/Contents/Default.aspx

Bloomberg. (2020). Data pergerakan Yield tenor seri Benchmark. Diakses pada 4 April 2020.

Direktorat Jenderal Pengelolaan Pembiayaan dan Risiko. (2020). Surat Utang Negara Seri Benchmark Tahun 2020. Diakses pada 1 Maret 2020,https://www.djppr.kemenkeu.go.id/page/loadViewer?idViewer=9300\&actio $\mathrm{n}=$ download

Fabozzi, FJ. Fabozzi, TD. \& Pollack., M. (2002). The Handbook of Fixed Income Securities. New York (US): Dow Jones-Irwinn.

Hsing, Y. (2015). Determinants of the Government Bond Yield in Spain: A Loanable Funds Model. International Journal of Financial Studies, 3(3), 342-350.

Indonesia Stock Exchange. (2020). Surat Utang. Diakses pada 4 April 2020, (https://www.idx.co.id/produk/surat-utang-obligasi/).

Kurniasih, A., \& Restika, Y. (2015). The influence of Macroeconomic Indicators and Foreign Ownership on Government Bond Yields: A Case of Indonesia. Mediterranean Journal of Social Sciences, October.

Listiawati, Laras., \& Paramita, V. (2018). Pengaruh Tingkat Suku Bunga, Inflasi, Debt to Equity Ratio, dan Ukuran Perusahaan terhadap Yield Obligasi pada Perusahaan yang terdaftar di Bursa Efek Indonesia tahun 2015 - 2016. Skripsi. Fakultas Ekonomi dan Bisnis, Univesitas Jenderal Achmad Yani, Semarang.

Madura, Jeff. (2009). International Corporate Finance. Edisi 8. Buku 1. Jakarta: Salemba Empat.

Mankiw, N. G., Euston Quah, \& Peter, Wilson. (2012). Pengantar Ekonomi Makro. Edisi Asia. Jakarta: Salemba Empat.

Murtianingsih. (2012). Variabel Ekonomi Makro dan Indeks Harga Saham Gabungan. Jurnal Manajemen dan Akuntansi, 1 (3).

Nielsen, Mads S,. (2012). The Empirical Relationship between CDS Prices and Bond Yields after the Financial Crisis. Master's Thesis. Copenhagen Business School Department of Finance.

Penilai Harga Efek Indonesia (PHEI). (2020). Data Pasar Surat Utang. Diakses pada 19 Juni 2020,http://www.ibpa.co.id/DataPasarSuratUtang/HargadanYieldHarian /tabid/84/Default.aspx

Saputra, Tiyas Ardian \& Prasetiono. (2014). Analisis Faktor-Faktor Yang Mempengaruhi Yield Obligasi Konvensional Di Indonesia (Studi Kasus Pada Perusahaan Listed Di BEI). Jurnal Studi Manajemen \& Organisasi 11 (2014) Juni 67-77.

Sihombing, Pardomuan. (2014). Determinan Yield Curve Surat Utang Negara (SUN). Disertasi. Institut Pertanian Bogor, Bogor.

Sihombing, Pardomuan \& Hary Saputra Sundoro. (2017). Pengaruh Faktor Makroekonomi dan Likuiditas terhadap Yield Curve Obligasi Pemerintah Indonesia. Media Ekonomi, Vol. 25 No. 2 Oktober 2017: 117-132.

Shim, Ilhyock \& Haibin Zhu. (2010). The Impact of CDS Trading on the Bond Market: Evidence From Asia', Monetary and Economic Department. BIS Working Papers No 332.

Tandelilin, Eduardus. (2010). Portofolio dan Investasi Teori dan Aplikasi. Edisi pertama, Yogyakarta : Kanisius.

Wulandari, D. (2017). Pengaruh Tingkat Asuku Bunga, Peringat Obligasi dan Debt to 
Equity Ratio (DER) terhadap Yield Obligasi Korporasi (Studi Kaus Pada Seluruh Perusahaan Penerbit Obligasi Yang Terdaftar Di BEI Periode 2013-2015). Universitas Mercu buana, Jakarta.

Yuliawati, D., \& Suarjaya, A. (2017). Pengaruh Umur Obligasi, Tingkat Suku Bunga, Dan Inflasi Pada Imbal Hasil Obligasi Pemerintah Di Bei. None, 6(11), 254500. 